\title{
Ancient Tales of Giants from Qumran and Turfan
}

\author{
Contexts, Traditions, and Influences \\ Ed. by Matthew Goff, Loren T. Stuckenbruck, and Enrico Morano
}

[Antike Geschichten von Riesen aus Qumran und Turfan. Kontexte, Traditionen und Einflüsse.]

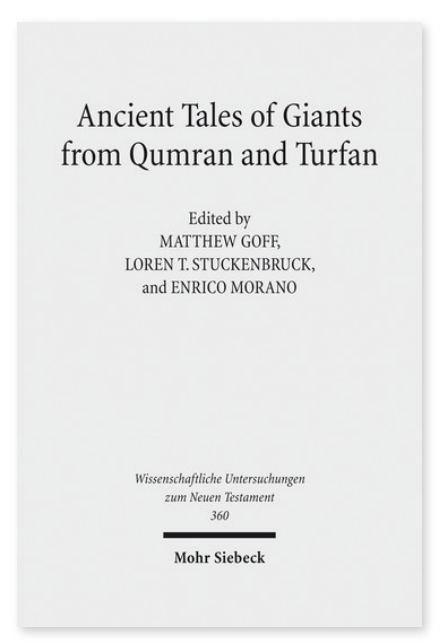

2016. XII, 257 Seiten. WUNT I 360

ISBN 978-3-16-154532-0

DOI 10.1628/978-3-16-154532-0

eBook PDF 139,00€

ISBN 978-3-16-154531-3

Leinen $139,00 €$
Veröffentlicht auf Englisch.

Während das henochische Buch der Wächter in der Wissenschaft viel Aufmerksamkeit erhält, findet das Gigantenbuch von Qumran viel weniger Beachtung. Dieser Band ist das Ergebnis einer Tagung in München im Juni 2014, die sich mit Riesen in der henochischen Tradition und vor allem im qumranischen Gigantenbuch beschäftigte. Die Beiträge befassen sich mit dem Thema der Riesen in verschiedenen antiken Kontexten, einschließlich der hebräischen Bibel, den Schriftrollen vom Toten Meer und dem antiken Mesopotamien. Die Verfasser richten ihr Augenmerk vor allem auf den Manichäismus, besonders auf das manichäische Gigantenbuch, dessen Fragmente in Turfan, in Westchina, gefunden wurden. Sie liefern einen wichtigen Beitrag zum Verständnis der Bandbreite der Geschichten, die die Juden einander in der Antike über die Söhne der Wächter erzählten, die auf die Erde herabstiegen, und deren reges Nachleben im Manichäismus.

Inhaltsübersicht

\section{Matthew Goff: Introduction}

Part One: Gibborim and Gigantes: Antecedents, Reception, and Comparative Contexts from the Hebrew Bible and Greek Literature

Brian R. Doak: The Giant in a Thousand Years: Tracing Narratives of Gigantism in the Hebrew Bible and Beyond - Samantha

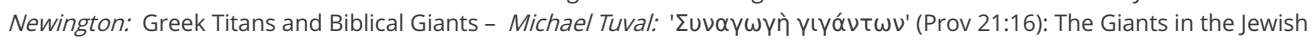
Literature in Greek

Part Two: Tales of Giants in their Ancient Jewish Context: the Dead Sea Scrolls, the Book of Watchers, and Daniel Joseph L. Angel: The Humbling of the Arrogant and the 'Wild Man' and 'Tree Stump' Traditions in the Book of Giants and Daniel 4 - Amanda M. Davis Bledsoe: Throne Theophanies, Dream Visions, and Righteous(?) Seers: Daniel, the Book of Giants, and 1 Enoch Reconsidered - Ida Fröhlich: Giants and Demons - Matthew Goff: The Sons of the Watchers in the Book of Watchers and the Qumran Book of Giants: Contexts and Prospects - Loren T. Stuckenbruck: The Book of Giants among the Dead Sea Scrolls: Considerations of Method and a New Proposal on the Reconstruction of 4Q530

Part Three: Enochic Traditions in Central Asia and China: Exploring Connections and Affinities between Giants in Ancient Judaism and Manichaeism

Gábor Kósa: The Book of Giants Tradition in the Chinese Manichaica - Enrico Morano: Some New Sogdian Fragments Related to Mani's Book of Giants and the Problem of the Influence of Jewish Enochic Literature - John C. Reeves: Jacob of Edessa and the Manichaean Book of Giants? - Jens Wilkens: Remarks on the Manichaean Book of Giants: Once Again on Mahaway's Mission to Enoch

Matthew Goff is Professor of Hebrew Bible and Second Temple Judaism in the Department of Religion at Florida State University.

Loren T. Stuckenbruck Born 1960; BA Milligan College; MDiv and PhD Princeton Theological Seminary; since 2012 Chair of New Testament Studies (with Emphasis on Ancient Judaism) at Ludwig Maximilian University of Munich, Germany.

Enrico Morano is retired teacher of Classics in High Schools and the current President of the International Association of Manichaean Studies (IAMS).

Jetzt bestellen:

https://mohrsiebeck.com/buch/ancient-tales-of-giants-from-qumran-and-turfan-9783161545320?no_cache=1 order@mohrsiebeck.com

Telefon: +49 (0)7071-923-17

Telefax: +49(0)7071-51104 